\title{
LEGITIMACY ASSESSMENT OF POLLEN WITH SIMPLE SEQUENCE REPEATS MARKERS
}

\author{
YEN-YEN KWAN*; EZDIAWATI YAHAYA*; NUR ADIBAH ISHAK** and LING-JIUN LEAO**
}

\begin{abstract}
It is essential that only good quality planting materials are used in oil palm breeding and commercial seed production. Best parents are usually selected from the best families for commercial production. Stringent quality measures of seed had already been employed to produce high quality planting materials. However, pollination with illegitimate pollen still arise in oil palm breeding programme and compromise quality of planting materials. To date, legitimacy of pollen is traced through data recording. Therefore, illegitimate pollen due to errors occur during pollen processing may have been overlooked. Concurring genotyping profiles generated by panel of Simple Sequence Repeats (SSR) markers in leaf and pollen grains of the same palm, facilitate assessment of pollen legitimacy. Utilisation of this assessment may exclude utilisation of illegitimate pollen in oil palm breeding programme and improve the quality of breeding procedure.
\end{abstract}

\section{Keywords: oil palm, pollen, SSR markers.}

Date received: 17 October 2016; Sent for revision: 16 March 2017; Received in final form: 3 August 2017; Accepted: 4 August 2017.

\section{INTRODUCTION}

Parentage information of families and individuals are very important in breeding programme as oil palm breeders usually select the best individual plants within the best families (Corley, 2005) based on progeny testing results. Progeny testing results of unknown illegitimate individuals in the families is not useful for selection process as the true parental is unknown and is therefore, cannot be exploited for commercial production and breeding improvement.

Illegitimacy and contamination did occur sporadically in the past as reflected by Pol820, which is the ancestor of AVROS materials (Corley, 2005). Typical detection of illegitimacy or contamination is through fruit typing which exhibits occurrences of unexpected fruit form or anomaly segregation ratios. Subsequent detection accuracy has improved tremendously with genetic markers, where discrimination between individuals can be

* Felda Global Ventures Research \& Development Sdn Bhd, FGV Innovation Centre, PT 23417 Lengkuk Technology, 71760 Bandar Enstek, Negeri Sembilan, Malaysia. E-mail: speedwell.yen@gmail.com

** Felda Global Venture Research \& Development Sdn Bhd, Pusat Penyelidikan Pertanian Tun Razak, 26400 Bandar Jengka, Pahang, Malaysia. performed based on variation in the genomic loci. Among the available genetic markers, microsatellite markers are the most widely used due to its straightforward PCR procedure and also providing informative alleles per locus.

Controlled pollination is susceptible to various sources of error, which could contribute to illegitimacy or contamination of a cross. Errors may occur in pollen collection or storage, labelling of pollinated bunches on the palm, seed storage, nursery or during field planting of the trials (Corley, 2005). Despite the implementation of quality control measures of seed production process (Chin, 1995) to produce high quality planting materials, utilisation of illegitimate pollen still lingers and detection remains a challenge. Here, we report that panel of Simple Sequence Repeats (SSR) markers is capable to assess pollen legitimacy and propose to be employed as QC tool in seed production process.

\section{MATERIALS AND METHODS}

\section{Plant Materials}

Pollen and leaf samples were collected from six designated palms at Pusat Penyelidikan Pertanian 
Tun Razak, Felda Global Venture Research \& Development Sdn Bhd (FGV), at Jerantut, Pahang, Malaysia. GMH-43, AB1-15, FJ2-7 and GNR-4 were pisifera of Yangambi origin. On the other hand, DF-64 and FJ6-3 were Ulu Remis Deli dura and introgressed NPM x Yangambi tenera, respectively.

\section{Extraction of Genomic DNA}

Genomic DNA was extracted from pollen and leaf as previously described by Seng and Faridah (2006). The concentration of the extracted genomic DNA for each sample was determined using Nanodrop ND-1000 spectrophotometer (Thermo Scientific, USA). The integrity of the extracted genomic DNA was evaluated by resolving on a $1 \%$ agarose gel stained with RedSafe ${ }^{\mathrm{TM}}$ (iNtRON Biotechnology Inc., Korea) and visualised with transilluminator (UVItec Limited, UK).

\section{Microsatellite Analysis}

Eight primers were selected from FGV's Microsatellite Legitimacy Panel Version 2.0 (Siti Hawa et al., 2015). These primers were selected based on SSR loci isolated by the French Centre de Coopération en Recherche Agronomique pour le Dévelopment (CIRAD) and Malaysian Palm Oil Board (MPOB) (Table 1). The forward primers were added with M13 sequence 5'-GGA AAC AGC TAT GAC CAT-3' (Oetting et al., 1995), permitting concurrent fluorescence labelling of polymerate chain reaction $(\mathrm{PCR})$ products by a third primer (M13) with an incorporated multiple fluorescent dye label $\left(6-\mathrm{FAM}^{\mathrm{TM}}, \mathrm{VIC}^{\circledR}, \mathrm{NED}^{\mathrm{TM}}\right.$ and $\left.\mathrm{PET}^{\circledR}\right)$ together with the reverse primer (Boutin-Ganache et al., 2001).

PCR amplification was performed in a $10 \mu \mathrm{l}$ reaction mixture containing $100 \mathrm{ng}$ genomic DNA, 1x MyTaq ${ }^{\mathrm{TM}} \mathrm{HS}$ mix, $0.42 \mu \mathrm{l}$ of primer mix $(10 \mu \mathrm{M}$ of M13-tailed forward primer, $10 \mu \mathrm{M}$ reverse primer and $1 \mu \mathrm{M}$ of fluorescent labelled-M13 primer).
TABLE 1. PRIMERS USED IN SIMPLE SEQUENCE REPEATS (SSR) ANALYSIS AND ALLELE SIZE OF EACH PRIMER

\begin{tabular}{lcc}
\hline Primer name & Repeat motif & Allele size \\
\hline mEgCIR0886 & $(\mathrm{GA})_{9}$ & $150-190$ \\
mEgCIR0894 & $(\mathrm{GA})_{18}$ & $170-230$ \\
mEgCIR2427 & $(\mathrm{GA})_{14}$ & $120-180$ \\
mEgCIR3358 & $(\mathrm{GA})_{15}$ & $200-260$ \\
mEgCIR3400 & $(\mathrm{GA})_{16}$ & $120-180$ \\
mEgCIR3428 & $(\mathrm{GA})_{15}$ & $160-200$ \\
$\operatorname{mEgCIR} 3663$ & $(\mathrm{GA})_{21}$ & $200-260$ \\
$\operatorname{mEgCIR3785}$ & $(\mathrm{GA})_{21}$ & $250-300$ \\
\hline
\end{tabular}

PCR amplifications were performed in Mastercyler pro S (Eppendorf, Germany) using the following programme; pre-denaturation at $95^{\circ} \mathrm{C}$ for $1 \mathrm{~min}$, followed by 35 cycles of $95^{\circ} \mathrm{C}$ for $15 \mathrm{~s}, 52^{\circ} \mathrm{C}-57^{\circ} \mathrm{C}$ for $15 \mathrm{~s}$ and $72^{\circ} \mathrm{C}$ for $10 \mathrm{~s}$. PCR amplicons were analysed along a size standard, (GeneScan ${ }^{\mathrm{TM}} 600$ LIZ $^{\circledR}$ Size Standard) using ABI3500XL Capillary Electrophoresis Genetic Analyser (Applied Biosystems, USA). The alleles were sized and genotyped using GeneMapper version 5.0 software (Applied Biosystems, USA).

\section{RESULTS AND DISCUSSION}

\section{Isolation of Genomic DNA from Pollen}

Genomic DNA was successfully extracted from the pollen collected from GMH-43, ABI-15, FJ217, GNR-4, FJ6-3 and DF-64 palms. Intact genomic DNA with no visible signs of DNA degradation were observed in the agarose gel (Figure 1). Purity of the extracted genomic DNA from pollen ranged from 1.74 to 1.86 , comparable to those extracted from leaf samples (Table 2). Utilising $0.1 \mathrm{~g}$ of pollen as starting material is sufficient to generate good quality of genomic DNA with the yields ranging between $38-51 \mu \mathrm{g}$ for subsequent SSR markers analysis.

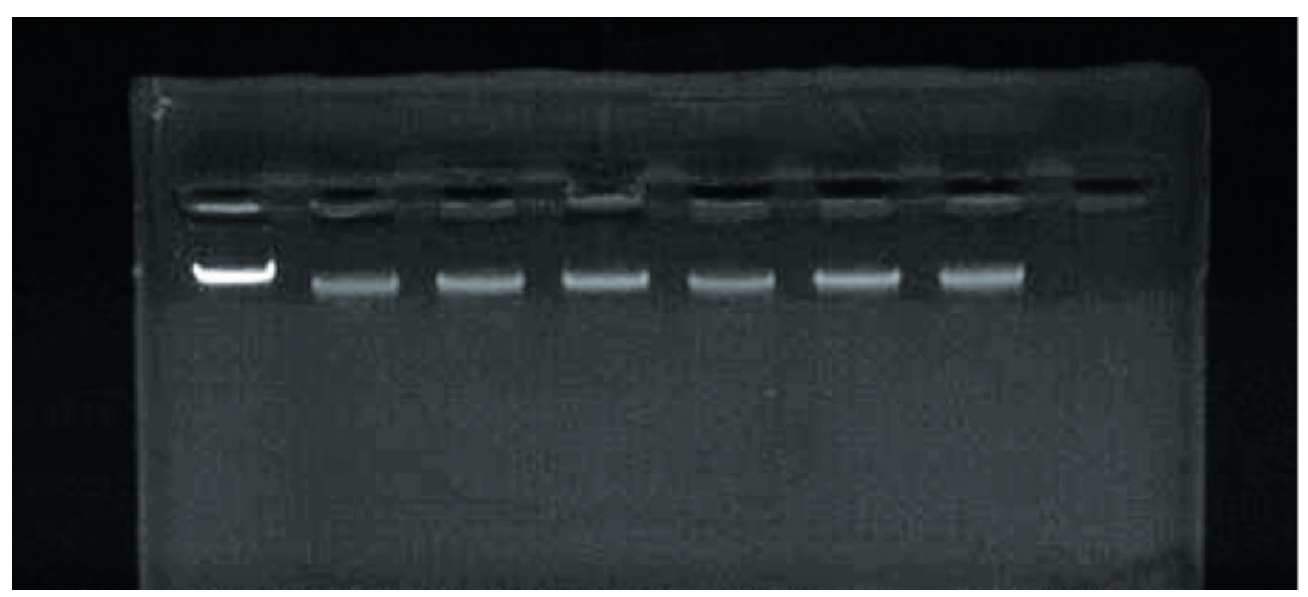

Figure 1. Genomic DNA extracted from pollen samples. Lane 1, Lambda DNA; 2, GMH-43; 3, ABI-15; 4, FJ2-7; 5, GNR-4; 6, FJ6-3 and 7, DF-64. 

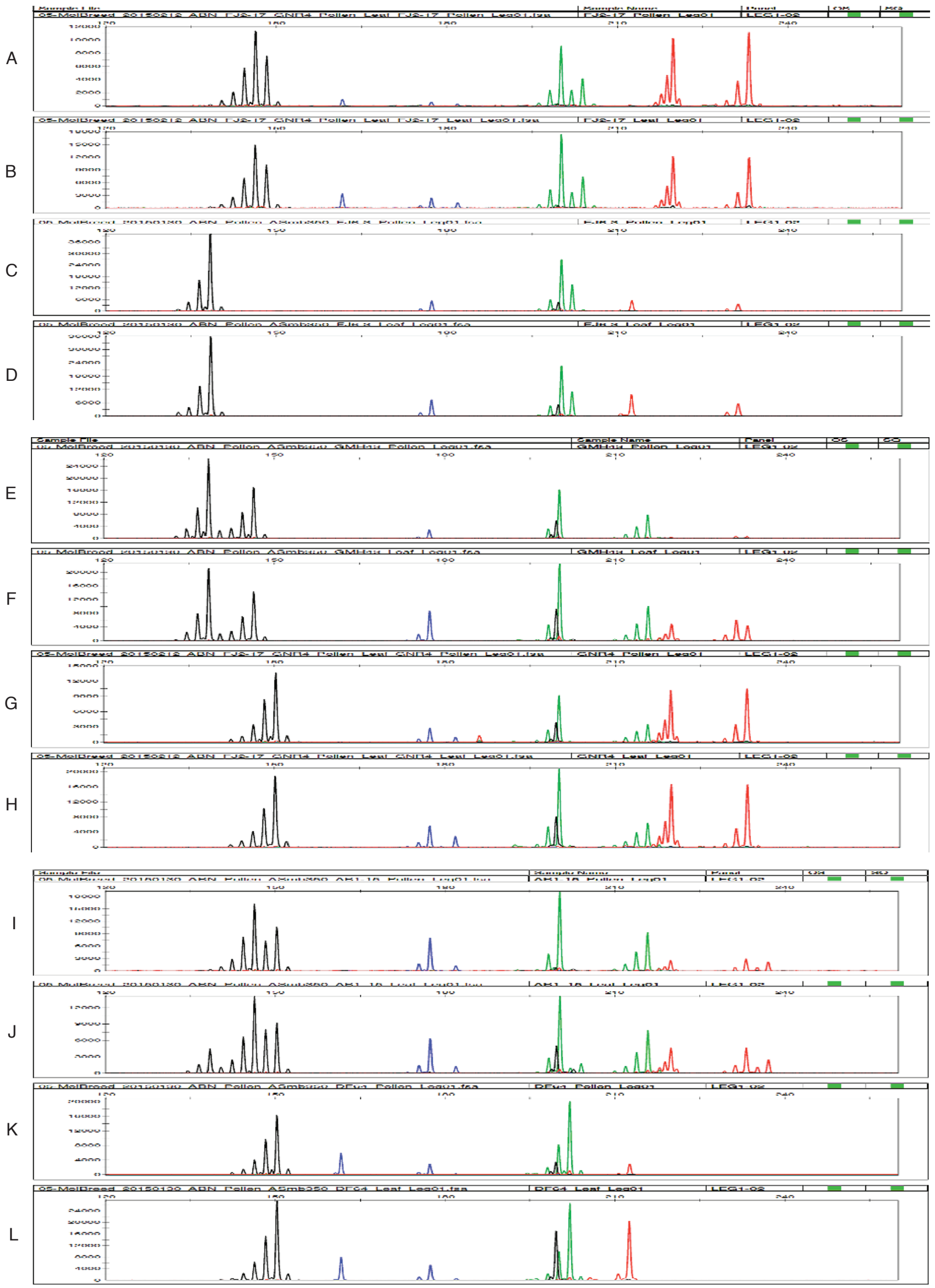

Figure 2. Electropherogram for Simple Sequence Repeats (SSR) marker analysis with mEgCIR0886 (blue), mEgCIR0894 (green), mEgCIR2427 (black) and $m E g C I R 3358$ (red) on pollen $(A, C, E, G, I, K)$ and leaf $(B, D, F, H, J, L)$. A and $B, A B 1-15 ; C$ and D, DF-64; E and F, FJ2-17; G and H, FJ6-3; I and J, GMH-43; K and L, GNR-4. The allele size of the amplicons is labelled in panel A, C, E G, I and $K$. 
TABLE 2. QUANTITY AND QUALITY OF THE EXTRACTED GENOMIC DNA

\begin{tabular}{llcc}
\hline Sample ID & Source & $\begin{array}{c}\text { DNA yield } \\
\left(\mathbf{n g} \mu \mathbf{l}^{-\mathbf{1}}\right)\end{array}$ & $\begin{array}{c}\text { DNA purity } \\
\left(\mathbf{A}_{\mathbf{2 6 0}} / \mathbf{A}_{\mathbf{2 8}}\right)\end{array}$ \\
\hline GMH-43 & Leaf & 443 & 1.79 \\
GMH-43 & Pollen & 346 & 1.85 \\
ABI-15 & Leaf & 336 & 1.80 \\
ABI-15 & Pollen & 291 & 1.83 \\
FJ2-17 & Leaf & 535 & 1.83 \\
FJ2-17 & Pollen & 254 & 1.80 \\
GNR-4 & Leaf & 501 & 1.82 \\
GNR-4 & Pollen & 255 & 1.85 \\
FJ6-3 & Leaf & 333 & 1.83 \\
FJ6-3 & Pollen & 307 & 1.86 \\
DF-64 & Leaf & 407 & 1.78 \\
DF-64 & Pollen & 284 & 1.74 \\
& & & \\
\hline
\end{tabular}

\section{Concurring Microsatellite Profiles in Leaf and Pollen Grains}

Microsatellite profiles derived from leaf exhibited one or two alleles per SSR marker indicating diploidy nature of oil palm. On the other hand, pollen grains are haploid and therefore should exhibit 1:1 segregation ratio in loci with two alleles in mother palm. Gómez et al. (2001) reported in vitro-induced haploid embryos from anther cultures of Quercus suber L. exhibiting parental tree segregation. Only one allele per locus was amplified in each embryo of the tested $Q$. petraea microsatellite loci. Furthermore, Mendelian segregation of 1:1, is statistically confirmed by squared test in one case.

As mix of pollen grains harvested from a male inflorescence were used for genomic DNA
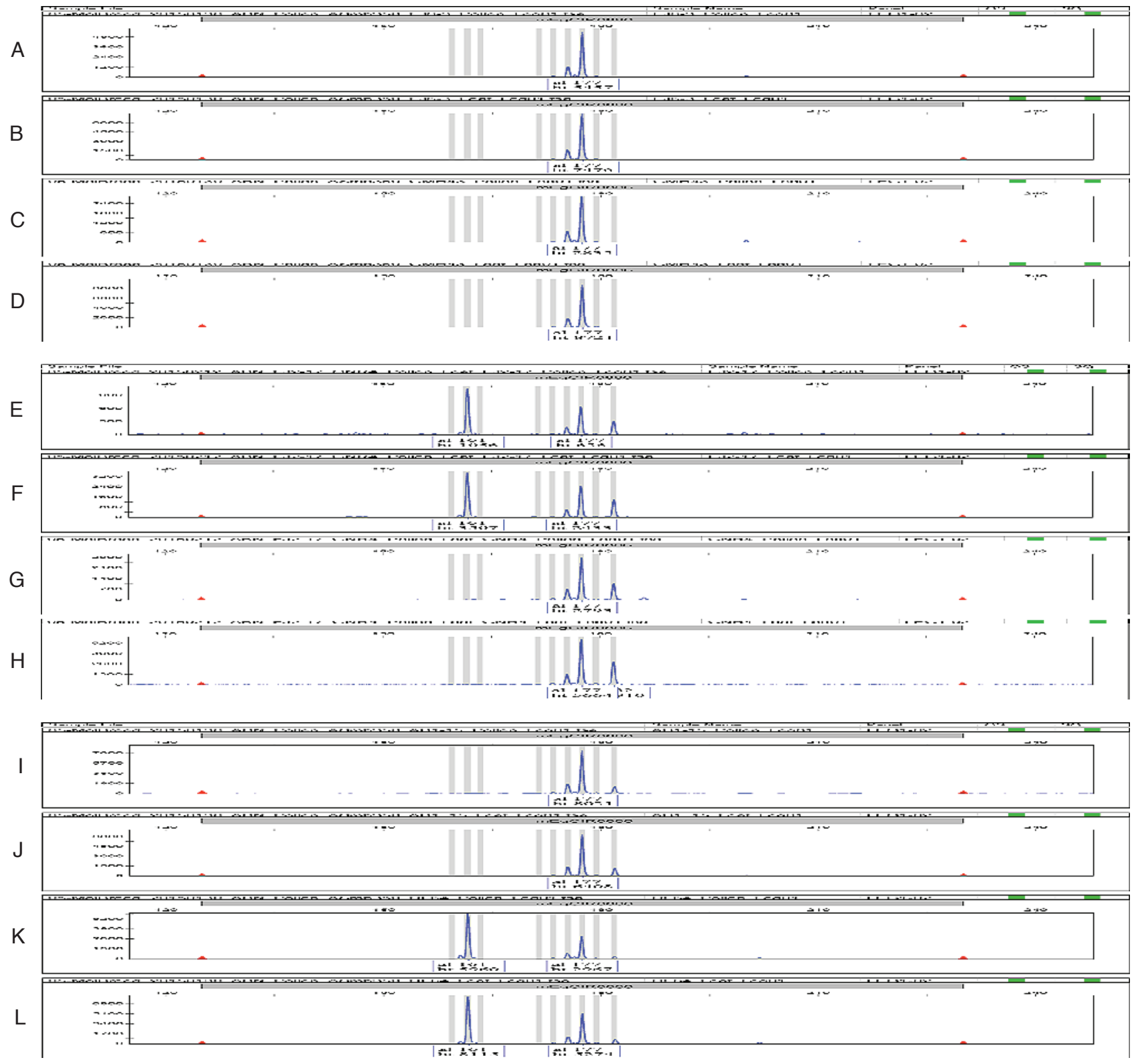

Figure 3. Electropherogram for Simple Sequence Repeats (SSR) marker analysis with mEgCIR0886 on pollen $(A, C, E, G, I, K)$ and leaf $(B, D, F, H, J$, L). A and B, AB1-15; C and D, DF-64; E and F, FJ2-17; G and H, FJ6-3; I and J, GMH-43; K and L, GNR-4. 
extraction, microsatellite profile generated by pollen DNA concurred with leaf profile of the same palm. No differences in microsatellite profiles were observed between leaf and pollen DNA of the same palm (Figures 2 and 3 ) in eight tested loci. Agreement of microsatellite profiles in leaf and pollen of the same palm indicating this molecular marker data comparison could be exploited as legitimacy tool for the harvested pollen.

\section{Quality Control on Breeding Procedure}

It is essential that crosses have to be made correctly to exclude illegitimacy and contamination in breeding programmes. Breeding glitches could occur at various stages, from pollen collection to field planting, compromising the quality of the breeding crosses made.

Utilisation of microsatellite markers in fidelity (Bakoume et al., 2011) and legitimacy testing (Hama-Ali et al., 2014; Siti Hawa et al., 2015) have been reported in oil palm with leaf genomic DNA. These testing hitherto conducted at the earliest in the nursery, after controlled pollination. However, oversight could also occur at the earlier stages, at pollen collection or storage.

Our results demonstrated concurrence profiles generated by SSR genotyping on pollen and leaf of the same palm, indicating legitimacy assessment of the harvested pollen can be determined before proceeding with cross pollination activity. Consolidating legitimacy assessment of pollen into standard operating procedure of breeding crosses could help to exclude the usage of incorrect pollen for pollination process and subsequently refine the quality control measures in seed production.

\section{CONCLUSION}

Concurring microsatellite profiles generated in leaf and pollen grains of the same palm demonstrated that it is viable to determine pollen status with panel of SSR markers. Integrating pollen legitimacy assessment into current standard operating procedure of seed processing will help to improve the quality of planting materials.

\section{ACKNOWLEDGEMENT}

The authors wish to thank their respective organisations for the support and permission to publish this article. We gratefully acknowledge the financial support from Felda Agricultural Services Sdn Bhd.

\section{REFERENCES}

BAKOUME, C; MOHAMAD, Y A; TANGAYA, P; THE, C K; YAHYA, S; MUSA, H; JANGI, $\mathrm{M}$ S; BASIRAN, $\mathrm{M}$ N; HASHIM, $\mathrm{K}$ and KULAVEERASINGAM, H (2011). DNA sequencebased markers for verification of ramet-to-ortet relationship in oil palm (Elaeis guineensis Jacq.). American J. Plant Sciences, 2: 539-548.

BOUTIN-GANACHE, I; RAPOSO, M; RAYMOND, $\mathrm{M}$ and DESCHEPPER, C F (2001). M13-tailed primers improve the readability and usability of microsatellite analyses performed with two different allele-sizing methods. Biotechniques, 31(1): 24-28.

CHIN, C W (1995). Quality of oil palm planting materials - breeding, seed production and nursery practices. Paper presented at the PORIM National Oil Palm Conference. 11-12 July 1995. Kuala Lumpur, Malaysia.

CORLEY, R H V (2005). Illegitimacy in oil palm breeding: a review. J. Oil Palm Res. Vol. 17: 64-69.

GÓMEZ, A, PINTOS, B, AGUIRIANO, E; MANZANERA, J A and BUENO, M A (2001). SSR markers for Quercus suber tree identification and embryo analysis. J. Heredity, 92(3): 292-295.

HAMA-ALI E, O; SYED ALWEE, S S R; TAN, S G; PANANDAM, J M; HO C L; NAMASIVAYAM, P and $\mathrm{HOH}, \mathrm{B}$ P (2014). Illegitimacy and sibship assignments in oil palm (Elaeis guineensis Jacq.) half-sib families using single locus DNA microsatellite markers. Molecular Biology Reports, 42(5): 917-925.

OETTING, W S; LEE, H K; FLANDERS, D J; WIESNER, G L; SELLERS, T A and KING, R A (1995). Linkage analysis with multiplexed short tandem repeat polymorphisms using infrared fluorescence and M13 tailed primers. Genomics, 30(3): 450-458.

SENG, T Y and FARIDAH, Q Z (2006). DNA extraction from mature oil palm leaves. J. Oil Palm Res. Vol. 18: 219-224.

SITI HAWA, M S; SENG, T Y; NURUL HAFIZA, $\mathrm{R}$; LEAO, L J; MOHD LATIF, K; RAO, V and SHARIFAH SHAHRUL RABIAH, S A (2015). DNA fingerprinting of FGV elite Yangambi. Paper presented at the $2^{\text {nd }}$ International Conference on Crop Improvement. 2-3 December 2015. Serdang, Selangor, Malaysia. 